GRASAS Y ACEITES 67 (3)

July-September 2016, e145

ISSN-L: 0017-3495

doi: http://dx.doi.org/10.3989/gya.0323161

\title{
Impact of olive oil usage on physical properties of chocolate fillings
}

\author{
J.M. Dias ${ }^{\mathrm{a}, \bowtie}$, M. Almeida ${ }^{\mathrm{a}}$, D. Adikevičius ${ }^{\mathrm{b}}$, P. Andzevičius ${ }^{\mathrm{b}}$ and N.B. Alvarenga ${ }^{\mathrm{a}, \mathrm{c}, \mathrm{d}}$ \\ ${ }^{a}$ ESA, Instituto Politécnico de Beja, Rua de Pedro Soares, 7800-295 Beja, Portugal \\ ${ }^{b}$ Vilnius College/University of Applied Sciences, Saltoniškių Str. 58, LT - 08105 Vilnius, Lithuania \\ ${ }^{c}$ LEAF, Tapada da Ajuda, 1349-017 Lisbon, Portugal \\ ${ }^{\mathrm{d}}$ GeoBioTec Research Institute, Universidade Nova de Lisboa. Campus da Caparica, 2829-516 Caparica, Portugal \\ ${ }^{\square}$ Corresponding author: joao.dias@ipbeja.pt
}

Submitted: 05 March 2016; Accepted: 21 April 2016

SUMMARY: The development of a new olive oil based chocolate filling was carried out. In this study three different types of virgin olive oil were tested, in three different concentrations in the production of chocolate fillings. An instrumental analysis was carried out for chemical analyses, such as moisture and $\mathrm{pH}$. The color analysis included the CIE $1976 \mathrm{~L} * \mathrm{a} * \mathrm{~b} *$ color space and RGB color space. The rheological analysis included the evaluation of flow curve, flow index (n), consistency $(\mathrm{K})$ and dynamic moduli ( $G$ ' and $\mathrm{G}^{\prime}$ ). No influence was detected on the moisture or $\mathrm{pH}$ of chocolate fillings, due to the concentration or type of olive oil. However, the use of olive oil decreased consistency from $1371 \mathrm{Pas}^{\mathrm{n}}$ to 148 - $559 \mathrm{Pas}^{\mathrm{n}}$, even using olive oil concentrations of $20 \% \mathrm{w} / \mathrm{w}$. Also, G' registered a similar correlation, where a decrease was observed from $4.42 \times 10^{6} \mathrm{~Pa}$ to values around $1.70-2.51 \times 10^{6} \mathrm{~Pa}$, for $20 \% \mathrm{w} / \mathrm{w}$ olive oil. The fillings presented a darker yellow-green color when using olive oil produced with Galega and Cordovil de Serpa varieties, but olive oil produced with the Arbequina variety did not affect color significantly, although further studies will be required to evaluate the impact of ripening stage.

KEYWORDS: Chocolate; Color; Filling; Olive oil; Rheology; Viscosity

RESUMEN: Impacto del uso del aceite de oliva en las propiedades físicas de relleno de chocolate. Ha sido desarrollado un nuevo relleno basado en aceite de oliva. En este estudio se testaron tres tipos diferentes de aceite de oliva, en tres concentraciones diferentes en la producción de rellenos de chocolate. El análisis instrumental incluyó análisis químico, como humedad y pH. El análisis del color incluyó el espacio CIE 1976 L*a*b* y el espacio RGB. El análisis reológico incluyó la evaluación del índice de flujo (n), consistencia (K) y módulos dinámicos (G’ y G’'). Ni se detectó influencia en la humedad ni el pH de rellenos debido a la concentración o el tipo de aceite. Sin embargo, el uso de aceite de oliva disminuyó la consistencia desde 1371 Pas $^{\mathrm{n}}$ a 148 - 559 Pas $^{\mathrm{n}}$, incluso usando concentraciones bajas de aceite como $20 \% \mathrm{~m} / \mathrm{m}$. Por otra parte, también G' presentó una correlación similar, donde se observó una disminución de $4.42 \times 10^{6}$ Pa para valores alrededor de 1.70-2.51 x $10^{6}$ $\mathrm{Pa}$, también con $20 \% \mathrm{~m} / \mathrm{m}$ aceite. Los rellenos presentaron un color más oscuro amarillo-verde cuando se utilizó el aceite producido con las variedades Galega y Cordovil de Serpa, pero el aceite producido con la variedad Arbequina no afectó significativamente al color, no obstante, serán necesarios más estudios para evaluar el impacto de la maduración.

PALABRAS CLAVE: Aceite de oliva; Chocolate; Color; Relleno; Reologia; Viscosidad

Citation/Cómo citar este artículo: Dias JM, Almeida M, Adikevičius D, Andzevičius P, Alvarenga NB. 2016. Impact of olive oil usage on physical properties of chocolate fillings. Grasas Aceites, 67 (3): e145. doi: http://dx.doi.org/10.3989/ gya. 0323161 .

Copyright: (C) 2016 CSIC. This is an open-access article distributed under the terms of the Creative Commons Attribution-Non Commercial (by-nc) Spain 3.0 Licence. 


\section{INTRODUCTION}

In handmade chocolates, the most common type of filling is "ganache", a mixture of chocolate and cream, where other products can be added to improve flavor or shelf life. The "ganache" is a multiphase system and consists of an emulsion of two immiscible liquids, the water present in the cream and the fat present in cream, chocolate or other added products (Dias et al., 2015). For greater stability, the emulsion must present yield stress and the forces applied by the disperse phase on the continuous phase (e.g. gravity and buoyant force) must be lower than the value of the yield stress (Rao, 2007). The use of cocoa butter and other fats in handmade chocolates is crucial to obtain a smooth and pleasant texture for the consumer but it also contributes to a longer shelf life, due to the lower moisture content (Saha and Bhattacharya, 2010). In addition, fat plays an important role in the overall sensory impression (Beckett, 2008) and in the stability of emulsions, due to fat crystallization, which prevents the sedimentation of water droplets by the formation of a threedimensional network (Ushikubo and Cunha, 2014). However, one of the main components of chocolate is cocoa butter, where the saturated fatty acid content can represent about $62 \%-65 \%$ of the total fatty acids (Torres-Moreno et al., 2015). The possibility of a partial replacement of cocoa butter by another vegetable fat with greater benefits to health would represent an important advance in reducing the negative impacts of high density products, like chocolate or pastry. Virgin olive oil is one of the components of the Mediterranean diet and must be obtained from the fruit of the olive tree by mechanical or other physical means under conditions that do not lead to alterations in the oil (Franco et al., 2014). Virgin olive oils include important elements like vitamins, phenolic compounds with antioxidant capacity, but are mainly composed of triacylglycerols (TAG), free fatty acids (FFA), together with other minor elements but have a positive impact on human health (Perona and Botham, 2013).

The aim of this work was the evaluation of appearance, rheological behavior and physical properties of fillings using olive oil as a partial chocolate replacement. Several samples were produced using cream, white chocolate and olive oil in different concentrations and from different varieties of olives. In addition, a sample of chocolate filling with no added olive oil was used as the control sample.

\section{MATERIALS AND METHODS}

\subsection{Preparation of samples}

Nine different fillings were produced in a local confectionery (Sugar Bloom/Mestre Cacau, Beja, Portugal), using white chocolate
TABLE 1. Characterization of olive oil

\begin{tabular}{llll}
\hline Olive oil & Type of olive oil & \multicolumn{1}{c}{$\begin{array}{c}\text { Predominant } \\
\text { varieties of olives }\end{array}$} & Origin \\
\hline GC & Virgin olive oil & $\begin{array}{l}\text { Galega } \text { and Cordovil } \\
\text { de Serpa }\end{array}$ & Portugal \\
Arb & Virgin olive oil & Arbequina & Spain \\
ArbD & Bleached olive oil & Arbequina & Spain \\
\hline
\end{tabular}

TABLE 2. Formulation of fillings

\begin{tabular}{lccccc}
\hline & & & \multicolumn{3}{c}{ Olive oil } \\
\cline { 5 - 6 } $\begin{array}{c}\text { Sample } \\
\text { code }\end{array}$ & $\begin{array}{c}\text { Cream } \\
(\% \text { w/w })\end{array}$ & $\begin{array}{c}\text { Chocolate } \\
(\% \text { w/w })\end{array}$ & $\begin{array}{c}\text { GC } \\
(\% / w / w)\end{array}$ & $\begin{array}{c}\text { Arb } \\
(\% / w)\end{array}$ & $\begin{array}{c}\text { ArbD } \\
(\% \text { w/w })\end{array}$ \\
\hline $\begin{array}{l}\text { A0 } \\
\text { (Control })\end{array}$ & 20 & 80 & - & - & - \\
A20GC & 20 & 60 & 20 & - & - \\
A20Arb & 20 & 60 & - & 20 & - \\
A20ArbD & 20 & 60 & - & - & 20 \\
A25GC & 20 & 55 & 25 & - & - \\
A25Arb & 20 & 55 & - & 25 & \\
A25ArbD & 20 & 55 & - & - & 25 \\
A30GC & 20 & 50 & 30 & - & - \\
A30Arb & 20 & 50 & - & 30 & - \\
A30ArbD & 20 & 50 & - & - & 30 \\
\hline
\end{tabular}

(SicaoCDW-U2630-557), cream (30\% fat) and three different references of olive oil at three different concentrations $(20 \%, 25 \%$ and $30 \% \mathrm{w} / \mathrm{w})$, as described in Table 1. The preparation of fillings started by heating the cream up to $100{ }^{\circ} \mathrm{C}$, using a heating plate provided with a magnetic stirrer. After that, the heating plate was turned off and white chocolate and olive oil were added to the mixture using a double-blade hand blender to homogenize, according to the percentages presented in Table 2. A control sample was also prepared, with no olive oil. Finally, the fillings were kept at $25^{\circ} \mathrm{C}$ for twenty-four hours to totally crystallize the cocoa butter included in the white chocolate.

The olive oil reference "ArbD" started with a bleaching process of virgin olive oil "Arb". Virgin oil "Arb" was stirred with $2 \%$ w/w bleaching earth SepiGel Natural 200RF (Sepiolsa) for $120 \mathrm{~min}$ at $60{ }^{\circ} \mathrm{C}$. At the end of the bleaching process, the mixture was filtered using a Macherey-Nagel MN321 paper filter $(7-12 \mu \mathrm{m})$ and stored at $20^{\circ} \mathrm{C}$ in an Erlenmeyer flask covered with aluminum foil.

\subsection{Chemical analysis}

The $\mathrm{pH}$ was evaluated at $20 \pm 1{ }^{\circ} \mathrm{C}$ using a Metrohm $691 \mathrm{pH}$ Meter (Switzerland). Moisture content was evaluated using method 931.04 (AOAC, 1990). Determinations were made five times. 


\subsection{Color analysis}

\subsubsection{Digital image analysis}

The image analysis procedure of the prepared fillings was based on the literature (Briones and Aguilera, 2005; Nopens et al., 2008). An image analysis set up was built, using a Sony DSC-H50 digital camera (aperture $f / 7,1$, exposure 1/13 s, ISO-400, no zoom, no flash, 3456 x 2592 pixel, JPEG format 24-bit sRGB) and two CIE $\mathrm{D}_{65}$ lamps (Phillips TL-D 18W/965, Netherlands). The sample was placed on a blank sheet of paper, the camera was placed vertically $10 \mathrm{~cm}$ above the sample and both lamps were placed at $42 \mathrm{~cm}$ from the sample with an angle of $45^{\circ}$ to avoid shadows on the sample (Figure 1). The image was standardized with a Minolta CR-A43 white ceramic plate $(\mathrm{Y}=92.7, \mathrm{x}=0.3159, \mathrm{y}=$ $0.3324)$. The images were collected in quintuplicate and analyzed using the software IMAQ Vision Builder (National instruments, USA). The first step was the extraction of the Region of Interest (ROI) of each image, corresponding to the surface of the chocolate fillings (Figure 2). The second step was the adjustment of brightness and contrast, using the Minolta standardized white plate. Finally, the third step was the RGB analysis of the ROI. The value of luminance $(\mathrm{Y})$ was calculated using RGB values, as presented in Eq. (1), according to Recommendation ITU-R BT.601-7:

$$
\mathrm{Y}=\operatorname{int}(0.299 \mathrm{R}+0.587 \mathrm{G}+0.114 \mathrm{~B})
$$

\subsubsection{Colorimeter}

The color of the fillings was evaluated using a Minolta CR300 chroma-meter with an $8 \mathrm{~mm}-$ diameter measuring area, using diffuse illumination provided by a pulsed xenon arc lamp, and a $0^{\circ}$ viewing angle. A calibration was made using a Minolta CR-A43 white calibration plate ( $\mathrm{Y}=92.7$,

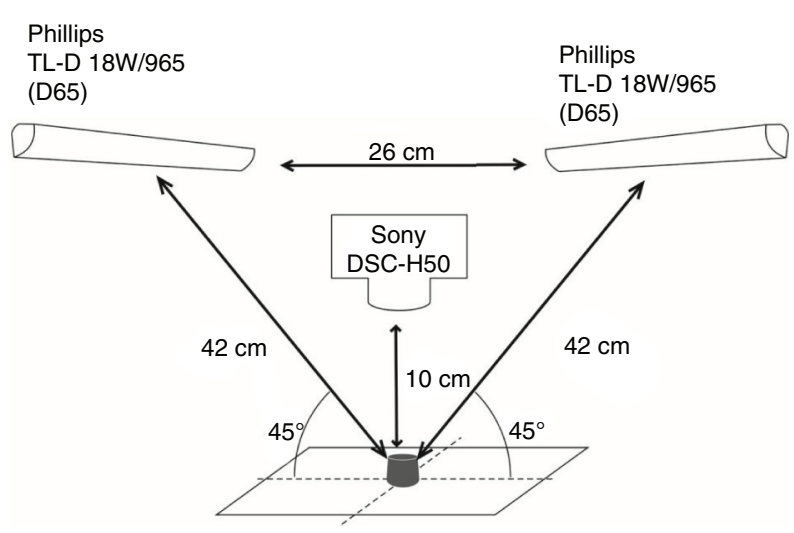

Figure 1. Digital image analysis set up.

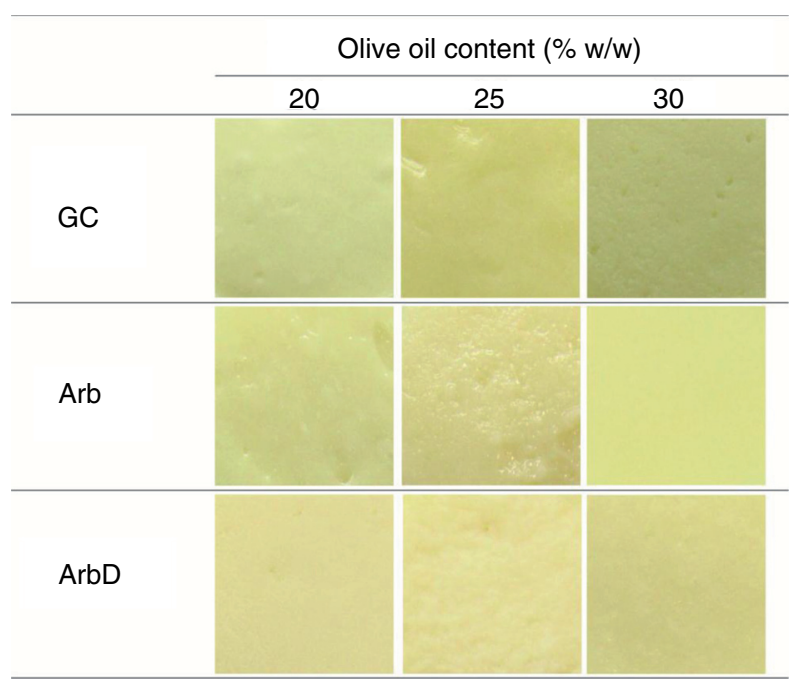

Figure 2. Digital image of chocolate fillings.

$\mathrm{x}=0.3134, \mathrm{y}=0.3195$ ) set to CIE standard illuminate $\mathrm{C}$. Absolute measurements were taken in quintuplicate and recorded as CIE $1976 \mathrm{~L}^{*} \mathrm{a} * \mathrm{~b} *$ color system. The parameter $L^{*}$ is the lightness variable and ranges from 0 (black) to 100 (white), the chromaticity coordinate $a^{*}$ ranges from green (negative) to red (positive), the chromaticity coordinate $\mathrm{b}^{*}$ ranges from blue (negative) to yellow (positive).

The color of olive oil samples was evaluated based on recent investigations (Morelló et al., 2003; Moyano et al., 2008). The olive oil was stored in flasks covered with aluminium foil until color measurements were made, which were carried out in a spectrophotometer Lico 620 UV-Vis (Germany) using $50 \mathrm{~mm}$ path length cuvettes. The spectra ranged from $380 \mathrm{~nm}$ to $720 \mathrm{~nm}(\Delta \lambda=10 \mathrm{~nm})$, using a CIE illuminate $\mathrm{C}$ (halogen lamp) and $2^{\circ}$ standard observer. This evaluation was made in quintuplicate. The tristimulus values were calculated according to CIE 1931 standards. The conversion to chromatic coordinates $\mathrm{x}, \mathrm{y}, \mathrm{z}$ was made according to Hunth and Pointer (2011). The conversion to color system CIE $1976 \mathrm{~L} * \mathrm{a} * \mathrm{~b} *$ was made according to MacDougall (2002).

\subsection{Rheological analysis}

The viscosity measurement of olive oil was carried out with a VT 550 rotational viscometer (Thermo Haake, Germany), using the concentric cylinder MV-DIN at $20{ }^{\circ} \mathrm{C}$. The tests were conducted with a controlled shear rate (from 200 to $1000 \mathrm{~s}^{-1}$ ). The obtained flow curves were evaluated according to the Newton model. Determinations were done in quintuplicate. The flow curves of the chocolate fillings were carried out with a VT 550 rotational viscometer (Thermo Haake, Germany) 
using cone-and-plate geometry at $20{ }^{\circ} \mathrm{C}$. The measuring device was PK1 $1^{\circ}(10 \mathrm{~mm} \varnothing)$. Shear stress ranged from 10 to $1000 \mathrm{~s}^{-1}$. Water was pumped into the jacketed vessel of the viscometer (Grant LTD6G) to control the temperature of the samples at $20 \pm 1{ }^{\circ} \mathrm{C}$ during measuring. The obtained flow curves were evaluated according to the rheological model of Ostwald, referred to also as the Power law model and used in previous studies on chocolate (Dias et al., 2015). Determinations were made in quintuplicate. This model is represented in Eq. (2):

$$
\sigma=K \gamma^{n}
$$

Where $\sigma$ is the shear stress $(\mathrm{Pa}), K$ is consistency index $\left(\mathrm{Pa} . \mathrm{s}^{\mathrm{n}}\right), \gamma$ is the shear rate $\left(\mathrm{s}^{-1}\right)$ and $n$ is the dimensionless flow behavior index.

Small amplitude oscillatory measurements of chocolate fillings were performed using a controlled shear-strain rheometer (Malvern Kinexus lab+, England) connected to a refrigeration circuit with controlled temperature. The visco-elastic behavior of the fillings was evaluated at $20^{\circ} \mathrm{C}$ using a $4 \% 40 \mathrm{~mm}$ cone and plate geometry and gap distance of $1 \mathrm{~mm}$. First, excess sample was trimmed with a thin plastic blade and the sample was allowed to rest for $5 \mathrm{~min}$ for temperature equilibrium. Later, the linear viscoelastic region (LVR) was evaluated by performing a strain sweep $(0.001 \%-1000 \%)$ at a steady frequency of $1 \mathrm{~Hz}$. Finally, the dynamic frequency sweep was conducted applying a steady strain of $0.01 \%$, within the LVR, from $0.001 \mathrm{~Hz}$ to $100 \mathrm{~Hz}$. The rheological parameters for this study were the storage $\left(G^{\prime}\right.$, in $\mathrm{Pa})$ loss $(\mathrm{G}$, , in $\mathrm{Pa})$ moduli.

\subsection{Statistical analysis}

Average, standard deviation and 0.95 confidence interval values were determined. Experimental data was subjected to one-way ANOVA (pair-wise comparison of means with the Scheffé test) in order to find differences in samples with different concentrations of olive oil. The data was analyzed using Statistica 6.0 (Statsoft, Tulsa, USA). The principal component analysis (PCA) was carried in order to evaluate the importance of the use of olive oil in the production of the fillings (Alvarenga et al., 2011).

\section{RESULTS AND DISCUSSION}

\subsection{Evaluation of olive oil}

The spectral power distribution of olive oils GC and Arb were similar and both presented lower transmittance values than ArbD in every wavelength. Both (GC and $\mathrm{Arb}$ ) presented a maximum transmittance peak at $580-600 \mathrm{~nm}$ followed by a decrease to $610 \mathrm{~nm}$ (Figure 3). In both cases the

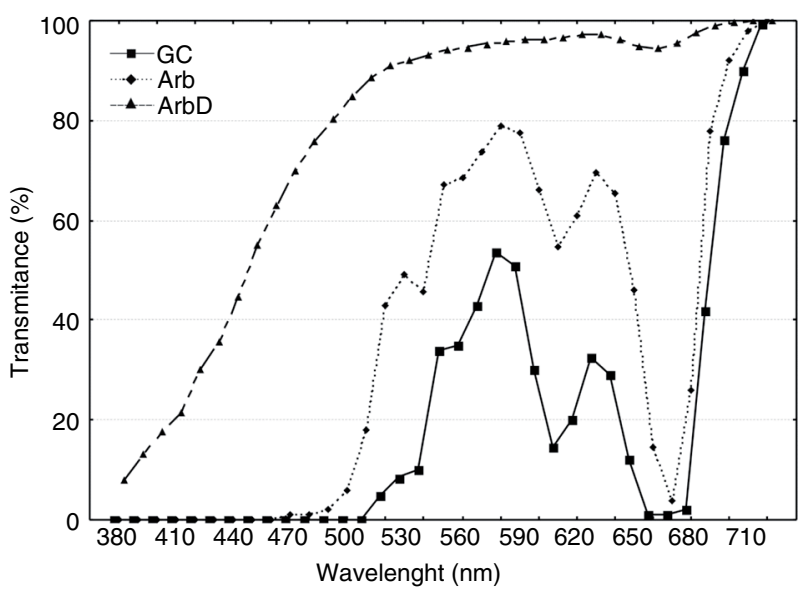

FIGURE 3. Spectral power distribution of olive oils $(n=5)$.

minimum valued was recorded at $670 \mathrm{~nm}$, identified as the spectral range with the highest absorbance of pheophytin"a", the major fraction of chlorophyll (Fuentes de Mendoza, 2013), and usually used to evaluate the chlorophyll content of olive oil (Morelló et al., 2003). On the other hand, wavelength $470 \mathrm{~nm}$ was identified as the wavelength with the highest absorbance by lutein, the major fraction of carotenoids (Morelló et al., 2003) presenting antioxidant activity and recommended to prevent some types of cancer (Limón et al., 2015). These results indicate that olive oil GC presented the highest contents in chlorophyll and carotenoids, followed by Arb and finally ArbD.

Table 3 presents the estimated tristimulus (XYZ) and CIE $1976 \mathrm{~L}^{*} \mathrm{a}^{*} \mathrm{~b}^{*}$ values, based on the spectral power distribution. The tristimulus values presented significant differences $(\mathrm{P}<0.05)$ among the three olive oils, according to the visual perception. The highest values were recorded for olive oil ArbD (lighter appearance) and the lowest were recorded for olive oil GC (darker appearance). Also, parameter L* from CIE 1976 color space was the highest for $\operatorname{ArbD}\left(\mathrm{L}^{*}=94.8\right)$, followed by Arb $\left(\mathrm{L}^{*}=78.7\right)$ and, finally, $\mathrm{GC}\left(\mathrm{L}^{*}=56.5\right)$. Similar results for the Arbequina variety were observed by Moyano et al. (2008). The observed L*a*b* values were consistent with other studies on color analysis of olive oil, especially $\mathrm{L}^{*}$ and $\mathrm{b}^{*}$ parameters (Moyano et al., 2008; Pérez et al., 2003). The values of Arb were similar to the results of olive oils from the Extremadura region (Spain) produced with Morisca and Carrasqueña varieties (Fuentes de Mendoza, 2013). Parameter a* presented the highest values for $\mathrm{GC}$ olive oil $\left(\mathrm{a}^{*}=3.6\right)$, followed by $\operatorname{Arb}\left(a^{*}=-6.4\right)$ and $\operatorname{ArbD}\left(a^{*}=-10.7\right)$. Parameter $\mathrm{b}^{*}$ presented positive values in all samples and the results of GC and ArbD were similar to olive oils using the Morisca and Carrasqueña varieties (Fuentes de Mendoza, 2013). 
TABLE 3. Physical evaluation of olive oils $(n=5)$

\begin{tabular}{lccccccc}
\hline Olive oil & $\mathbf{X}$ & $\mathbf{Y}$ & $\mathbf{Z}$ & $\mathbf{L}^{*}$ & $\mathbf{a}^{*}$ & $\mathbf{b}^{*}$ & $\begin{array}{c}\text { Viscosity } \\
(\mathbf{m P a} . \mathbf{s})\end{array}$ \\
\hline GC & 24,8 & 24,4 & 0,2 & 56,5 & 3,6 & 103,1 & 87,16 \\
& $(0.12)$ & $(0.11)$ & $(0.0)$ & $(0.1)$ & $(0.0)$ & $(0.1)$ & $(0.4)$ \\
Arb & 50,8 & 54,3 & 1,5 & 78,7 & $-6,4$ & 116,5 & 92,26 \\
& $(0.2)$ & $(0.2)$ & $(0.0)$ & $(0.1)$ & $(0.0)$ & $(0.2)$ & $(0.7)$ \\
ArbD & 79,8 & 87,1 & 57,1 & 94,8 & $-10,7$ & 34,0 & 61,03 \\
& $(3.9)$ & $(4.2)$ & $(2.7)$ & $(1.8)$ & $(0.0)$ & $(0.6)$ & $(1.4)$
\end{tabular}

Standard deviation is stated in parentheses.

The viscosity of olive oil ranged from $61.03 \mathrm{mPas}$ (ArbD) to $92.26 \mathrm{mPas}$ (Arb), similar to other results on virgin olive oils at $20^{\circ} \mathrm{C}$ (Gila et al., 2015). The lowest viscosity value was observed in the bleached olive oil ArbD (61.03 mPas).

\subsection{Evaluation of chocolate fillings}

The moisture values of chocolate fillings ranged from $8.3 \%$ (A20ArbD) to $13.1 \%$ (A25Arb), as a consequence of the added cream. As shown in Table 4, the results of moisture content of formulations using olive oil presented higher values than the control sample $(\mathrm{P}<0.05)$, except for sample A20ArbD. However, no differences were expected due to the same cream content in all formulations and the same moisture content both in the white chocolate and the olive oil $(<1 \% \mathrm{w} / \mathrm{w})$ used in the preparation of the samples. The results of moisture content were lower compared with other studies, due to the lower cream content $(20 \%$ cream w/w), instead of the common value $30-40 \%$ cream w/w (Wybauw, 2010). The $\mathrm{pH}$ values were lower in the control sample $(\mathrm{pH}=5.79)$. The formulations using olive oil presented $\mathrm{pH}$ values from 5.91 (A25GC) to 5.97 (A25ArbD, A30ArbD), but no correlation was observed between added olive oil and $\mathrm{pH}(\mathrm{P} \geq 0.05)$. Figure 4 presents the results of all chocolate fillings on the $\mathrm{a}^{*}$ and $\mathrm{b}^{*}$ components of the CIE 1976 color space. Based on the olive oil, the identification of three main clusters is noticeable: GC (lower values of $\mathrm{a}^{*}$ and higher values of $\mathrm{b}^{*}$ ), Arb (central values of $\mathrm{a}^{*}$ and $\mathrm{b}^{*}$ ) and Control/ArbD (higher values of $a^{*}$ and lower values of $\left.b^{*}\right)$. The results of the colorimeter for the chocolate fillings presented higher $\mathrm{L}^{*}$ value for the control sample $\left(\mathrm{L}^{*}=82.0\right)$, with no addition of olive oil, and all results presented a negative correlation between added olive oil and $\mathrm{L}^{*}$ (Table 4). This influence was most noted using GC olive oil, followed by Arb olive oil and less noted using ArbD olive oil, as a consequence of the $\mathrm{L}^{*}$ of the olive oil (Table 3). Both parameters $a^{*}$ and $b^{*}$ were influenced by the type and concentration of olive oil. And, as expected, the highest shift from the control sample was observed when using GC olive oil at $30 \% \mathrm{w} / \mathrm{w}$.
As mentioned before, luminescence $(\mathrm{Y})$ was calculated based on the RGB data obtained from the digital image analysis and values ranged from 0 (black) to 255 (white). The highest value for luminescence was observed in the control sample $(Y=225)$, followed by Arb and ArbD olive oil, with no significant differences $(P \geq 0.05)$. On the other hand, the lowest value was obtained in the chocolate fillings produced with GC olive oil, presenting a negative correlation with olive oil $(\mathrm{P}<0.05)$. The results of the digital image analysis were consistent with the colorimeter results and both $\mathrm{Y}$ and $\mathrm{L}^{*}$ presented higher values in the control sample and lower values in the sample coded A30GC.

The results of the image and color analyses conclude that ArbD is the olive oil with the best ability to maintain the original appearance of conventional chocolate fillings and, on the other hand, GC olive oil considerably changes the fillings to a more yellow-green color. Nevertheless, sample A20GC, due to the lower olive oil content did not affect color by as much as $25 \%$ and $30 \% \mathrm{w} / \mathrm{w}$.

The Power Law model was used to evaluate consistency (K) and flow index (n). The results showed that all formulations presented shearthinning behavior. Nevertheless, a significant gap was observed between the control sample $(n=0.01)$ and formulations using olive oil $(0.13<n<0.25)$. As expected, the results of flow index presented a negative correlation with consistency, as reported in previous studies on chocolate beverages (Dogan et al., 2011; Yanes et al., 2002), low-fat chocolate fillings (Dias et al., 2015) and low-fat dairy desserts (González-Tomás et al., 2008). The highest value of consistency $(\mathrm{K})$ was observed in the control sample $\left(\mathrm{K}=1371 \mathrm{Pas}^{\mathrm{n}}\right)$ and a significant decrease due to olive oil was observed in all formulations (Table 4), probably due to higher content in unsaturated fatty acids in virgin olive oil (Gila et al., 2015) compared with cocoa butter (Torres-Moreno et al., 2015). These results are consistent with previous studies reporting the relation between lower solid fat content and lower chocolate viscosity (Rothkopfand Danzl, 2015; Talbot, 2009), where the main identified causes were the increase in liquid content, TAG with a different nature and a different chain length from cocoa butter (Rothkopf and Danzl, 2015).

Although differences were observed in the viscosity of the tested olive oils (Table 3), no influence on the consistency of chocolate fillings was observed.

The results obtained from the rheometer (Table 4) showed that the control sample presented a higher value for the storage module $\mathrm{G}_{1 \mathrm{~Hz}}\left(4.42 \times 10^{6} \mathrm{~Pa}\right)$, than the fillings using olive oil $\left(0.28 \times 10^{6} \mathrm{~Pa}\right.$ to $\left.2.51 \times 10^{6} \mathrm{~Pa}\right)$. These results are coherent with consistency K (Table 4) and reflect the importance of cocoa butter in the structure of chocolate products (Dias et al., 2015; Afoakwa, 2010). The use of olive oil caused a decrease in storage module $G^{\prime}{ }_{1 \mathrm{~Hz}}$, 
TABLE 4. Effect of type and concentration of olive oil on mean values (standard deviation) of physical and chemical properties of chocolate fillings $(n=5)$

\begin{tabular}{|c|c|c|c|c|c|c|c|c|c|c|}
\hline $\begin{array}{l}\text { Sample } \\
\text { code }\end{array}$ & $\begin{array}{c}\text { Olive oil } \\
(\% \mathrm{w} / \mathrm{w})\end{array}$ & $\begin{array}{c}\text { Moisture } \\
(\% \mathrm{w} / \mathrm{w})\end{array}$ & pH & $\mathbf{L}^{*}$ & $a^{*}$ & $\mathbf{b}^{*}$ & $\mathbf{Y}$ & $\mathbf{n}$ & $\begin{array}{c}\mathbf{K} \\
\left(\text { Pas }^{n}\right)\end{array}$ & $\begin{array}{c}\mathbf{G}^{\prime}{ }_{1 \mathrm{~Hz}} \\
\left(10^{6} \mathrm{~Pa}\right)\end{array}$ \\
\hline $\begin{array}{l}\text { A0 } \\
\text { (control) }\end{array}$ & 0 & $\begin{array}{l}9.7^{\mathrm{cd}} \\
(0.5)\end{array}$ & $\begin{array}{l}5.74^{\mathrm{b}} \\
(0.02)\end{array}$ & $\begin{array}{l}82.0^{\mathrm{a}} \\
(1.7)\end{array}$ & $\begin{array}{l}-4.8^{\mathrm{b}} \\
(0.1)\end{array}$ & $\begin{array}{c}18.4^{\mathrm{de}} \\
(0.4)\end{array}$ & $\begin{array}{l}225^{\mathrm{a}} \\
(0.6)\end{array}$ & $\begin{array}{l}0.01^{\mathrm{b}} \\
(0.01)\end{array}$ & $\begin{array}{l}1371^{\mathrm{a}} \\
(130)\end{array}$ & $\begin{array}{l}4.42^{\mathrm{a}} \\
(0.97)\end{array}$ \\
\hline A20GC & 20 & $\begin{array}{c}12.2^{\mathrm{ab}} \\
(0.7)\end{array}$ & $\begin{array}{l}5.94^{\mathrm{a}} \\
(0.04)\end{array}$ & $\begin{array}{l}76.4^{\mathrm{c}} \\
(0.5)\end{array}$ & $\begin{array}{l}-6.8^{\mathrm{cd}} \\
(0.1)\end{array}$ & $\begin{array}{l}22.8^{\mathrm{c}} \\
(0.6)\end{array}$ & $\begin{array}{l}214^{\mathrm{ab}} \\
(6.2)\end{array}$ & $\begin{array}{l}0.15^{\mathrm{ab}} \\
(0.03)\end{array}$ & $\begin{array}{c}447^{\mathrm{bc}} \\
(84)\end{array}$ & $\begin{array}{l}2.51^{\mathrm{b}} \\
(0.22)\end{array}$ \\
\hline A $25 \mathrm{GC}$ & 25 & $\begin{array}{c}10.9^{\mathrm{bc}} \\
(0.9)\end{array}$ & $\begin{array}{l}5.91^{\mathrm{a}} \\
(0.01)\end{array}$ & $\begin{array}{c}69.2^{\text {efg }} \\
(0.5)\end{array}$ & $\begin{array}{l}-8.7^{\mathrm{e}} \\
(0.1)\end{array}$ & $\begin{array}{l}26.8^{\mathrm{b}} \\
(0.6)\end{array}$ & $\begin{array}{l}202^{\mathrm{c}} \\
(5.4)\end{array}$ & $\begin{array}{l}0.25^{\mathrm{a}} \\
(0.01)\end{array}$ & $\begin{array}{l}93^{\mathrm{d}} \\
(14)\end{array}$ & $\begin{array}{l}0.37^{\mathrm{d}} \\
(0.07)\end{array}$ \\
\hline A30GC & 30 & $\begin{array}{c}11.7^{\mathrm{ab}} \\
(0.4)\end{array}$ & $\begin{array}{l}5.93^{\mathrm{a}} \\
(0.03)\end{array}$ & $\begin{array}{l}67.7^{\mathrm{g}} \\
(1.7)\end{array}$ & $\begin{array}{l}-8.7^{\mathrm{e}} \\
(0.2)\end{array}$ & $\begin{array}{l}32.3^{\mathrm{a}} \\
(1.6)\end{array}$ & $\begin{array}{l}178^{\mathrm{d}} \\
(2.2)\end{array}$ & $\begin{array}{l}0.18^{\mathrm{ab}} \\
(0.03)\end{array}$ & $\begin{array}{c}159^{\mathrm{cd}} \\
(28)\end{array}$ & $\begin{array}{l}0.28^{\mathrm{d}} \\
(0.05)\end{array}$ \\
\hline A20Arb & 20 & $\begin{array}{c}12.3^{\mathrm{ab}} \\
(0.5)\end{array}$ & $\begin{array}{l}5.93^{\mathrm{a}} \\
(0.06)\end{array}$ & $\begin{array}{l}76.2^{\mathrm{c}} \\
(0.3)\end{array}$ & $\begin{array}{l}-6.3^{\mathrm{c}} \\
(0.1)\end{array}$ & $\begin{array}{l}18.8^{\mathrm{d}} \\
(0.5)\end{array}$ & $\begin{array}{l}214^{\mathrm{ab}} \\
(7.7)\end{array}$ & $\begin{array}{l}0.13^{\mathrm{ab}} \\
(0.13)\end{array}$ & $\begin{array}{l}559^{\mathrm{b}} \\
(321)\end{array}$ & $\begin{array}{l}2.17^{\mathrm{bc}} \\
(0.16)\end{array}$ \\
\hline A25Arb & 25 & $\begin{array}{l}13.1^{\mathrm{a}} \\
(0.2)\end{array}$ & $\begin{array}{l}5.95^{\mathrm{a}} \\
(0.04)\end{array}$ & $\begin{array}{c}70.5^{\mathrm{de}} \\
(0.3)\end{array}$ & $\begin{array}{l}-7.2^{\mathrm{d}} \\
(0.1)\end{array}$ & $\begin{array}{l}21.5^{\mathrm{c}} \\
(0.4)\end{array}$ & $\begin{array}{l}212^{b c} \\
(5.0)\end{array}$ & $\begin{array}{c}0.19^{\mathrm{a}} \\
(0.08)\end{array}$ & $\begin{array}{c}150^{\mathrm{cd}} \\
(21)\end{array}$ & $\begin{array}{l}1.01^{\text {bcd }} \\
(0.63)\end{array}$ \\
\hline A30Arb & 30 & $\begin{array}{l}11.2^{\mathrm{cd}} \\
(0.6)\end{array}$ & $\begin{array}{l}5.91^{\mathrm{a}} \\
(0.04)\end{array}$ & $\begin{array}{c}68.2^{\mathrm{fg}} \\
(0.4)\end{array}$ & $\begin{array}{l}-7.2^{\mathrm{d}} \\
(0.5)\end{array}$ & $\begin{array}{l}22.5^{\mathrm{c}} \\
(2.0)\end{array}$ & $\begin{array}{l}220^{\mathrm{ab}} \\
(1.3)\end{array}$ & $\begin{array}{c}0.20^{\mathrm{a}} \\
(0.06)\end{array}$ & $\begin{array}{c}109^{\mathrm{cd}} \\
(46)\end{array}$ & $\begin{array}{l}0.68^{\mathrm{cd}} \\
(0.10)\end{array}$ \\
\hline A20ArbD & 20 & $\begin{array}{l}8.3^{\mathrm{d}} \\
(0.3)\end{array}$ & $\begin{array}{l}5.93^{\mathrm{a}} \\
(0.06)\end{array}$ & $\begin{array}{l}78.8^{\mathrm{b}} \\
(0.7)\end{array}$ & $\begin{array}{l}-5.0^{\mathrm{b}} \\
(0.1)\end{array}$ & $\begin{array}{c}16.0^{\mathrm{ef}} \\
(0.7)\end{array}$ & $\begin{array}{l}220^{\mathrm{ab}} \\
(2.9)\end{array}$ & $\begin{array}{l}0.22^{\mathrm{a}} \\
(0.04)\end{array}$ & $\begin{array}{c}148^{\mathrm{cd}} \\
(33)\end{array}$ & $\begin{array}{l}1.70^{\text {bcd }} \\
(0.41)\end{array}$ \\
\hline A25ArbD & 25 & $\begin{array}{c}12.5^{\mathrm{ab}} \\
(1.0)\end{array}$ & $\begin{array}{l}5.97^{\mathrm{a}} \\
(0.03)\end{array}$ & $\begin{array}{l}72.0^{\mathrm{d}} \\
(0.1)\end{array}$ & $\begin{array}{l}-4.2^{\mathrm{a}} \\
(0.1)\end{array}$ & $\begin{array}{l}15.0^{\mathrm{f}} \\
(0.2)\end{array}$ & $\begin{array}{l}223^{\mathrm{ab}} \\
(0.8)\end{array}$ & $\begin{array}{l}0.23^{\mathrm{a}} \\
(0.07)\end{array}$ & $\begin{array}{c}157^{\mathrm{cd}} \\
(89)\end{array}$ & $\begin{array}{l}0.73^{\mathrm{cd}} \\
(0.21)\end{array}$ \\
\hline A30ArbD & 30 & $\begin{array}{c}11.3^{\mathrm{bc}} \\
(0.2)\end{array}$ & $\begin{array}{l}5.97^{\mathrm{a}} \\
(0.03)\end{array}$ & $\begin{array}{c}70.1^{\text {def }} \\
(0.2)\end{array}$ & $\begin{array}{l}-4.6^{\mathrm{ab}} \\
(0.1)\end{array}$ & $\begin{array}{l}15.0^{\mathrm{f}} \\
(0.3)\end{array}$ & $\begin{array}{l}215^{\mathrm{ab}} \\
(4.8)\end{array}$ & $\begin{array}{l}0.15^{\mathrm{ab}} \\
(0.07)\end{array}$ & $\begin{array}{c}170^{\mathrm{cd}} \\
(80)\end{array}$ & $\begin{array}{l}0.41^{\mathrm{cd}} \\
(0.11)\end{array}$ \\
\hline
\end{tabular}

Within each column different letters indicate significantly different values according to post-hoc comparison (Scheffè's test) at $\mathrm{P} \leq 0.05$. Standard deviation is stated in parentheses.

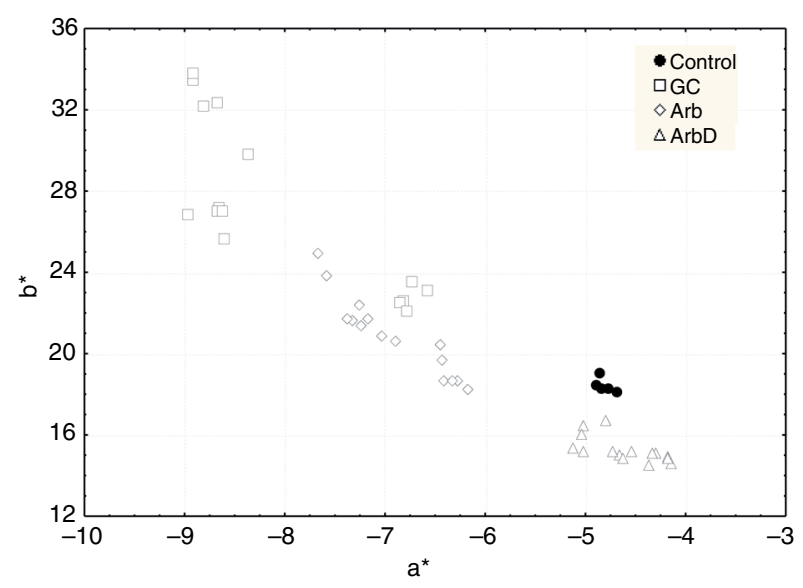

FIgURE 4. Color coordinates CIE $1976 \mathrm{a}^{*}$ and $\mathrm{b}^{*}$ of chocolate fillings.

compared with the control sample, even using an olive oil concentration of $20 \% \mathrm{w} / \mathrm{w}$, reflecting a less compact structure and a more liquid-like behavior (Di Mattia et al., 2015). The decrease in the storage module is a consequence of the olive oil composition, especially the larger content in unsaturated fatty acids and the different composition of triacylglycerols, compared with cocoa butter (Boskou, 2011). On the other hand, chocolate is a suspension of solid particles (like sugars, milk proteins, cocoa solids), around $30-50 \mu \mathrm{m}$ in diameter, in a continuous fat phase, mainly cocoa butter (Beckett, 2008). The addition of olive oil will contribute to the increase in continuous fat phase, thus decreasing the proportion of solid particles and, as a consequence, lower values of viscosity and G'.

The results of the ANOVA post-hoc comparison (Table 4) did not present an influence of the type of olive oil on the rheological behavior $(\mathrm{P} \geq 0.05)$. Nevertheless, the results of the principal component analysis (Figure 6) presented differences in the fillings produced with $\mathrm{ArbD}$ (lower $\mathrm{G}^{\prime}{ }_{1 \mathrm{~Hz}}$ ) and $\mathrm{GC}$ (higher $\mathrm{G}^{\prime}{ }_{\mathrm{Hz}}$ ), which is consistent with the results on the viscosity of the olive oils used (Table 3).

The frequency dependence of the dynamic moduli was evaluated and data from the storage module $\left(G^{\prime}\right)$ and loss module $\left(G^{\prime \prime}\right)$ are shown in mechanical spectra (Figure 5). The results of $G^{\prime}$ and $G$ " for the control sample presented limited dependency with frequency. In addition, the storage module $\left(G^{\prime}\right)$ presented higher values than the loss module (G'), especially from $0.01 \mathrm{~Hz}$ to $100 \mathrm{~Hz}$. These results are coherent with a gel structure. The use of olive oil caused a decrease in both storage and loss moduli and increased the dependency on frequency, especially between 0.001 and $0.1 \mathrm{~Hz}$. The presence of a crossover between dynamic moduli (i.e. $G^{\prime}=G^{\prime \prime}$ ) was observed at $30 \% \mathrm{w} / \mathrm{w}$ olive oil and, 

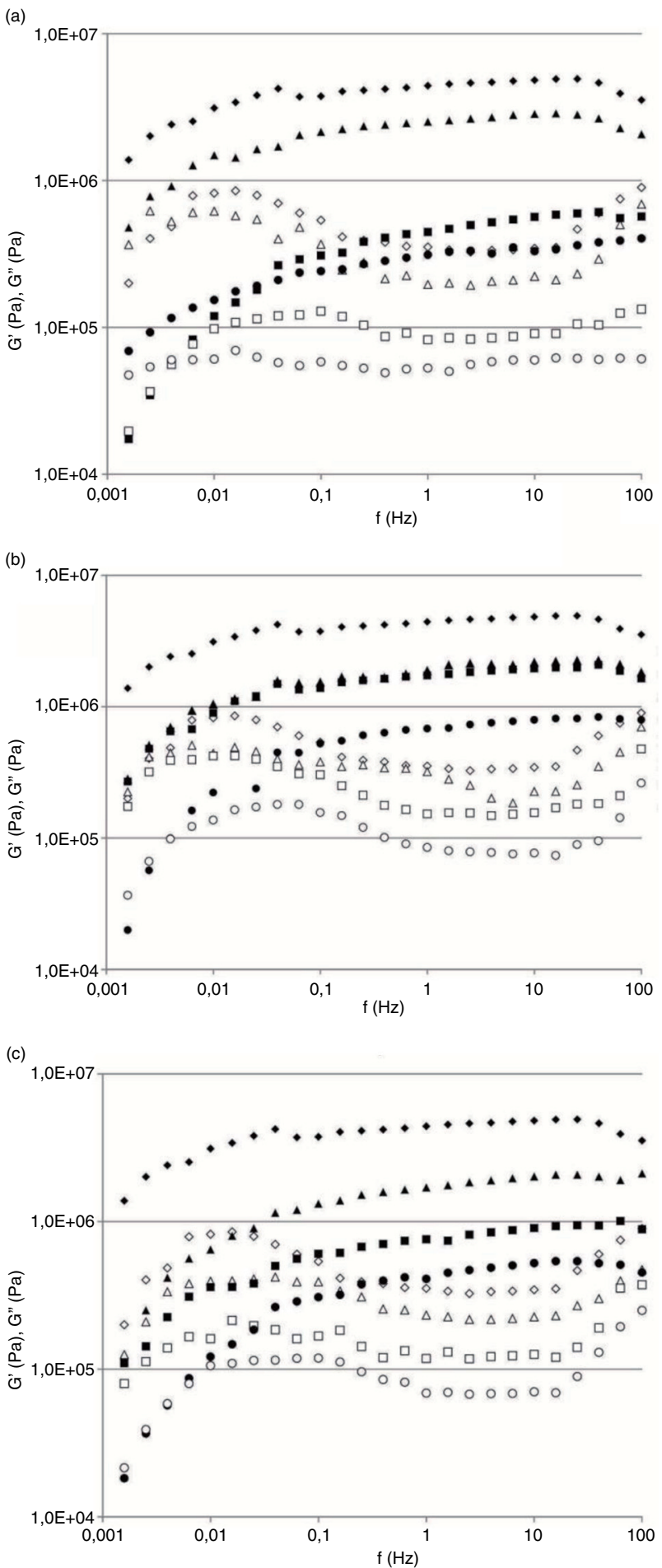

Figure 5. Storage (G') and loss (G") moduli of fillings ( $\mathrm{n}=5$ ) using GC (a), Arb (b) and ArbD olive oil (c).

Legend: Control sample ( $\left.\bullet G^{\prime} ; \diamond G^{\prime \prime}\right) ; 20 \%$ olive oil ( $\left.\wedge G^{\prime} ; \Delta G^{\prime \prime}\right)$, $25 \%$ olive oil (घG'; $\left.\square G^{\prime \prime}\right)$ and $30 \%$ olive oil ( $\left.\bullet G^{\prime} ; \circ G^{\prime \prime}\right)$.

as a consequence, can be assumed as the critical value defining the transition between a suspension and a gelled system (Lupi et al., 2013).

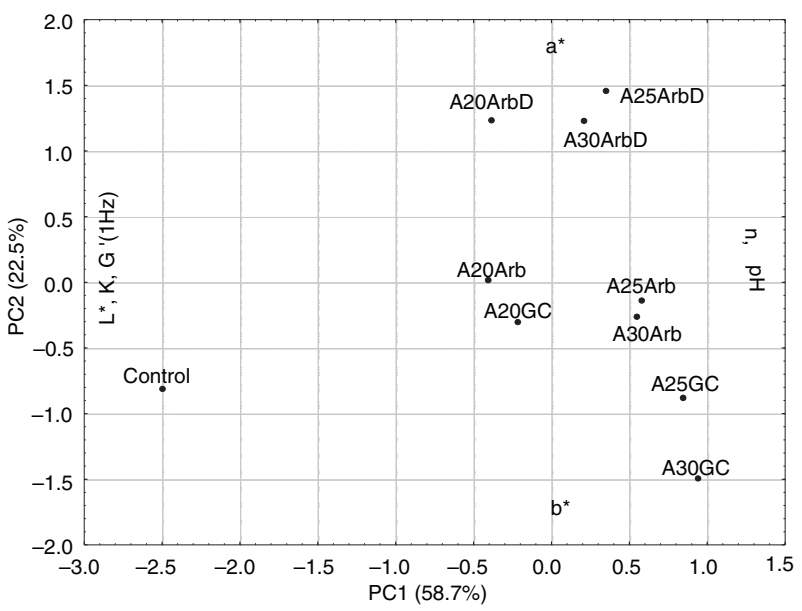

Figure 6. PC1 vs. PC2 projection of samples (average values, $n=5)$. The most important parameters for the definition of the two components are shown on the edge of each axis, indicating the direction in which the value of the parameter increases.

\subsection{Multivariate analysis}

A principal component analysis (PCA) was carried out with the color parameters $\mathrm{L}^{*} \mathrm{a}^{*} \mathrm{~b}^{*}$, two chemical parameters (moisture, $\mathrm{pH}$ ) and three rheological parameters $\left(\mathrm{G}_{1 \mathrm{~Hz}}, \mathrm{~K}, \mathrm{n}\right)$. Figure 6 shows the PC1 vs. PC2 projection of samples (average values) and, in the same plot, orientation of the parameters in the plot. The similarity map defined by the first two principal components took into account $81.2 \%$ of the total variance. The first component (PC1) by itself condensed $58.7 \%$ and the second component (PC2) represented $22.5 \%$ of the total variance. The PC1 presented negative correlations with the rheological parameters $\left(\mathrm{G}_{1 \mathrm{~Hz}}^{\prime}, \mathrm{K}\right)$ and $\mathrm{L}^{*}$ parameter and a positive correlation with the $\mathrm{n}$ flow index and $\mathrm{pH}$. The PC2 was negatively correlated to the $\mathrm{b}^{*}$ parameter and positively correlated with $\mathrm{a}^{*}$. Consequently, the results of the multivariate analysis confirmed the results previously obtained, showing the softening effect of olive oil over texture and the effect of GC olive oil on the darker color of chocolate fillings (Figure 6).

\section{CONCLUSIONS}

In conclusion, the obtained results provide useful information about new possible uses for olive oil in the chocolate or pastry industry. Olive oil can be incorporated into chocolate fillings with different outcomes, depending on the required features. The use of olive oils with predominance of the varieties Galega and Cordovil de Serpa will create smooth fillings with a yellow-green appearance. On the other hand, the use of bleached olive oil, based on the Arbequina variety, will create smooth fillings 
with a lighter appearance. However, although the variety of olives plays an important role in the properties of the olive oil, further studies will be required to evaluate the impact of the ripening stage.

\section{ACKNOWLEDGMENTS}

The authors are grateful to Sepiolsa (Spain) for their valuable help in providing the bleaching earth, and to Mestre Cacau/Sugar Bloom (Portugal) for providing the chocolate and facilities for the production of the samples.

\section{REFERENCES}

Afoakwa E. 2010. Chocolate Science and Technology. WileyBlackwell, Oxford

Alvarenga N, Canada J, Sousa I. 2011. Effect of freezing on the rheological, chemical and colour properties of Serpa cheese. J. Dairy Res. 78, 80-87. http://dx.doi.org/10.1017/ S0022029910000841

AOAC. 1990. Official methods of analysis of the Association of Official Analytical Chemists. Washington

Beckett S. 2008. The science of chocolate. 2nded. RSC Publishing, Cambridge

Boskou D. 2011.9 - Olive oil, in Gunstone FD (Ed.). Vegetable oils in food technology. Composition, properties and uses. Wiley-Blackwell, Oxford, 243-269.

Briones V, Aguilera J. 2005. Image analysis of change in surface colour of chocolate. Food Res. Int. 38, 87-94. http://dx.doi. org/10.1016/j.foodres.2004.09.002

Dias JM, Alvarenga NB, Sousa I. 2015. Effect of hydrocolloids on low-fat chocolate fillings. J. Food Sci. Techol. 52, 7209-7217. http://dx.doi.org/10.1007/s13197-015-1841-0

Di Mattia C, Balestra F, Sacchetti G, Neri L, Mastrocola D, Pittia P. 2015. Physical and structural properties of extravirgin olive oil based mayonnaise. LWT 62, 764-770. http:// dx.doi.org/10.1016/j.lwt.2014.09.065

Dogan M, Toker O, Goksel M. 2011. Rheological behavior of instant hot chocolate beverage: Part 1. Optimization of the effect of different starches and gums. Food Biophys. 6, 512-518. http://dx.doi.org/10.1007/s11483-011-9233-0

Franco MN, Galeano-Díaz T, Sánchez J, De Miguel C, MartínVertedor D. 2014. Antioxidant capacity of the phenolic fraction and its effect on the oxidative stability of olive oil varieties grown in the southwest of Spain. Grasas Aceites, 65, 1-10. http://dx.doi.org/10.3989/gya.051513

Fuentes de Mendoza M. 2013. Caracterización de los aceites de oliva virgen producidos en la zona oleícola de Tierra de Barros. Tesis doctoral. Universidad de Extremadura

Gila A, Jiménez A, Beltrán G, Romero A. 2015. Correlation of fatty acid composition of virgin olive oil with thermal and physical properties. Eur. J. Lipid Sci. Tech. 117, 366-376. http://dx.doi.org/10.1002/ejlt.201400078

González-Tomás L, Bayarri S, Taylor A, Costell E. 2008. Rheology, flavour release and perception of low-fat dairy desserts. Int. Dairy J. 18, 858-866. http://dx.doi. org/10.1016/j.idairyj.2007.09.010

Hunth RWG, Pointer MR. 2011. Measuring colour, 4th Ed, John Wiley \& Sons, West Sussex
Limón P, Malheiro R, Casal S, Acién-Fernández FG, FernándezSevilla JM, Rodrigues N, Cruz R, Bermejo R, Pereira JA. 2015. Improvement of stability and carotenoids fraction of virgin olive oils by addition of microalgae Scendesmus almeriensis extracts. Food Chem. 175, 203-211. http://dx.doi. org/10.1016/j.foodchem.2014.10.150

Lupi FR, Gabriele D, Greco V, Baldino N, Seta L, de Cindio B. 2013. A rheological characterization of an olive oil/ fatty alcohols organogel. Food Res. Int. 51, 510-517. http:// dx.doi.org/10.1016/j.foodres.2013.01.013

MacDougall DB. 2002. Colour in food. Improving quality. CRC Press, Cambridge

Morello JR, Motilva MJ, Ramo T, Romero MP. 2003. Effect of freeze injuries in olive fruit on virgin olive oil composition. Food Chem. 81, 547-553. http://dx.doi.org/10.1016/ S0308-8146(02)00488-0

Moyano MJ, Meléndez-Martínez AJ, Alba J, Heredia FJ. 2008. A comprehensive study on the colour of virgin olive oils and its relationship with their chlorophylls and carotenoids indexes (II): CIELUV and CIELAB uniform colour spaces. Food Res. Int. 41, 513-521. http://dx.doi.org/10.1016/j. foodres.2008.03.006

Nopens I, Foubert I, De Graef V, Van Laere D, Dewettinck K, Vanrolleghem P. 2008 Automated image analysis tool for migration fat bloom evaluation of chocolate coated food products. $L W T$ 41, 1884-1891. http://dx.doi.org/10.1016/j. lwt.2008.01.008

Pérez MM, Yebra A, Melgosa M, Bououd N, Asselman A, Boucetta A. 2003. Caracterización colorimétrica y clasificación del aceite de oliva virgen de la cuenca mediterránea hispano-marroquí. Grasas Aceites, 54, 392-396. http:// dx.doi.org/10.3989/gya.2003.v54.i4.226

Perona JS, Botham KM. 2013. Chapter 18 - Olive oil as functional food: nutritional and health beneficts, in Aparicio R, Harwood J (Eds.) Handbook of Olive Oil - Analysis and Properties. Springer, London, 677-714.

Rao M. 2007. Introduction: Food rheology and structure, in Rao MA (ed) Rheology of Fluid and Semisolid Foods. Principles and Applications. Springer, Geneva, 1-26.

Rothkopf I, Danzl W. 2015. Changes in chocolate crystallization are influenced by type and amount of introduced filling lipids. Eur. J. Lipid Sci. Technol. 117, 1714-1721. http:// dx.doi.org/10.1002/ejlt.201400552

Saha D, Bhattacharya S. 2010. Hydrocolloids as thickening and gelling agent in food: a critical review. J. Food Sci. Technol. 47, 587-597. http://dx.doi.org/10.1007/s13197-010-0162-6

Talbot G. 2009. Chapter 19 - Vegetable fats, in Beckett S (ed) Industrial Chocolate Manufacture and Use, 4th ed, Blackwell Publishing Ltd, Oxford, 415-433.

Torres-Moreno M, Torrescasana E, Salas-Salvadó J, Blanch C. 2015. Nutritional composition and fatty acids profile in cocoa beans and chocolates with different geographical origin and processing conditions. Food Chem. 166, 125-132. http://dx.doi.org/10.1016/j.foodchem.2014.05.141

Ushikubo FY, Cunha RL. 2014. Stability mechanisms of liquid water-in-oil emulsions. Food Hydrocolloid, 34, 145-153. http://dx.doi.org/10.1016/j.foodhyd.2012.11.016

Wybauw J. 2010. Fine chocolates - great experience 3. Extending shelf life. Lannoo Publishing nv, Tielt

Yanes M, Durán L, Costell E. 2002. Effect of hydrocolloid type and concentration on flow behaviour and sensory properties of milk beverages model systems. Food Hydrocolloid 16, 605-611. http://dx.doi.org/10.1016/ S0268-005X(02)00023-1 